\title{
Germination and initial growth of guava plants irrigated with saline water
}

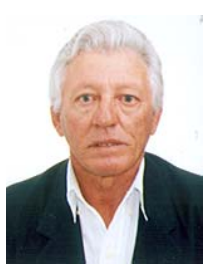

Lourival F. Cavalcante ${ }^{1}$, Ítalo H. L. Cavalcante ${ }^{2}$, Kátia S. N. Pereira ${ }^{3}$, Francisco A. de Oliveira1, Saulo C. Gondim ${ }^{1}$ \& Fernanda A. R. de Araújo ${ }^{4}$

\footnotetext{
1 Department of Soil Science and Rural Engineering, Center of Agrarian Sciences, Federal University of Paraíba, Brazil. Telephone: (83) 3362-2300. E-mail: lofeca@cca.ufpb.br (Photo); oliveira@cca.ufpb.br; saulogondim@cca.ufpb.br

2 Post graduate student. Department of Horticulture, UNESP. Via de Acesso Prof. Paulo Donato Castellane s/n, 14884 900, Jaboticabal, SP, Brazil. Telephone/Fax: (16) 3209-2668. E-mail: italohlc@fcav.unesp.br

3 CCA/UFPB, CEP 58397-000, Areia-PB. Telephone: (83) 3362-2300. E-mail: kátiapg@cca.ufpb.br

${ }^{4}$ Post graduate student. Department of Horticulture, Center of Agrarian Sciences, Federal University of Paraíba.Telephone: (83) 3362-2300. E-mail: fernandaararaujo@yahoo.com.br
}

Protocolo 135 - 3/9/2003 - Aprovado em 3/6/2005

\begin{abstract}
The present study was carried in order to evaluate the effect of saline water irrigation with electrical conductivity $\left(\mathrm{EC}_{\mathrm{w}}\right)$ of $0.5 ; 1.5 ; 3.0 ; 4.5$ and $6.0 \mathrm{dS} \mathrm{m}^{-1}$, on germination and some growth variables during the seedling formation process of four guava cultivars (Psidium guajava L.): Pentecoste, Paluma, Surubim and IPA B-38. Water salinity inhibited the germination process, plant height, stem diameter, leaf area and dry matter production of roots, stems and leaves, independently of cultivar. After germination, the seedlings did not survive due to saline water effects of $\mathrm{EC}_{\mathrm{w}} 4.5$ and $6.0 \mathrm{dS} \mathrm{m}^{-1}$. After 180 days of sowing, the seedlings irrigated with $\mathrm{EC}_{\mathrm{w}}$ more than $1.5 \mathrm{dS} \mathrm{m}^{-1}$ did not present agronomic quality for planting. Dry matter production sequence of different parts of plants was as follows: leaves $>$ roots $>$ stems, without significant differences among cultivars especially when irrigated with saline water of $\mathrm{EC}_{w}>3.0 \mathrm{dS} \mathrm{m}^{-1}$.
\end{abstract}

Key words: seedling production, salinity, Psidium guajava

\section{Germinação de sementes e crescimento inicial da goiabeira irrigada com água salina}

\begin{abstract}
Resumo: Avaliou-se o efeito da salinidade da água de irrigação, através dos níveis de condutividade elétrica $\left(\mathrm{CE}_{\mathrm{a}}\right)$ de 0,$5 ; 1,5 ; 3,0 ; 4,5$ e $6,0 \mathrm{dS} \mathrm{m} \mathrm{m}^{-1}$, sobre a germinação de sementes e algumas variáveis de crescimento, durante a formação de mudas de quatro cultivares de goiabeira (Psidium guajava L.) Pentecoste, Paluma, Surubim e IPA B-38. A salinidade da água inibiu a germinação, o crescimento em altura, diâmetro do caule, área foliar e fitomassa das raízes, caules e folhas das plantas, independente da cultivar. Após a germinação, as plântulas não sobreviveram aos efeitos salinos das águas de condutividade elétrica $\mathrm{CE}_{\mathrm{a}}$ 4,5 e 6,0 dS m $\mathrm{d}^{-1}$. Ao final do ensaio, 180 dias após a semeadura, não se obtiveram mudas com qualidade agronômica nos tratamentos irrigados com água de salinidade superior a $1,5 \mathrm{dS} \mathrm{m}^{-1}$. A ordem de produção de matéria seca pelos distintos órgãos das plantas, foi: folhas $>$ raízes $>$ caules, mas sem diferir entre cultivares, principalmente quando irrigadas com água de maior salinidade $>3,0 \mathrm{dS} \mathrm{m}^{-1}$.
\end{abstract}

Palavras-chave: produção de mudas, salinidade, Psidium guajava

\section{INTRODUCTION}

Guava (Psidium guajava L.) is a fruit of tropical climate, which presents good acceptance in Brazilian as well as in the external market. This is one of the reasons, besides the aroma, flavor and mineral-proteic quality that favors its cultivation as an economically promising activity. In the Northeastern part of Brazil, it is cultivated under irrigation and its productivity reaches more than $30 \mathrm{t} \mathrm{ha}^{-1}$, with the advantage of getting two or more harvests per year (Gonzaga Neto et al., 1982; Gonzaga Neto et al., 1999). However, in arid and semi-arid areas where the irrigation water has high salt content during dry period, this 
phenomenon negatively intervenes on seedling production and development of this considered sensible or moderately sensible to the salinity of soil and water (Ayers \& Westcot, 1999; Cavalcante \& Lima, 2000).

The salinity of water $\left(\mathrm{EC}_{\mathrm{w}}\right)$ or soil affect plant growth , direct or indirectly, partially or totally, slowly or brusquely, during germination process as well as in growth and development phases of the majority of plants (Bernstein, 1964) including passion fruit (Miguel et al., 1998; Cavalcante et al., 2001b), mango (Zuazo et al., 2003; Zuazo et al., 2004), pine cone (Lima et al., 2001b) and guava (Pereira, 2000; Távora et al., 2001).

The water constitutes a saline compost represented by cations and anions originally present in soil. Therefore, the continuous water use that offers moderate $\left(0.75<\mathrm{EC}_{\mathrm{w}}<3.0 \mathrm{dS}\right.$ $\left.\mathrm{m}^{-1}\right)$ and severe restriction $\left(\mathrm{EC}_{\mathrm{w}}>3.0 \mathrm{dS} \mathrm{m}^{-1}\right)$ can provoke toxic problems in plants and degrade the physical properties of soil. In these situations, the monitoring of water quality exerts importance on germination process, seedling production and establishment of majority of the plants (Ayers \& Westcot, 1999).

The increase of saline concentration reduces the water energy state of the soil, expressed by water and osmotic potentials and demands more energy by plant for water absorption. During germination phase, this phenomenon promotes higher salt absorption by seeds which commonly reflects negatively on germination process, as proposed by Mayer \& Poljakoff-Mayber (1989) and Santos (1999).

Specially for guava, Kaul et al. (1988) after studying the effects of sodium chloride, sodium sulphate, calcium chloride and its mixtures under three electrical conductivity levels, evidenced that the increase of $\mathrm{EC}_{\mathrm{w}}$ inhibited the germination, roots and hypocotyls growth of plants, independent of the source. They also concluded that, the sodium chloride was more harmful than calcium chloride and sodium sulphate.

Makhija et al. (1980), Kaul (1981) and Hooda \& Yamdagni (1991) evaluated the salinity effect on different phases of guava plants and concluded that saline stress inhibited the plant growth during its vegetative cycle, however, higher sensitivity has been evidenced during germination. This observation diverges from that of Pereira (2000) who reported that guava genotypes were more sensible to salinity during seedling formation phase.

The objective of this study was to evaluate effects of salinity of the irrigation water on germination and growth of four guava genotypes.

\section{MATERIAL AND METHODS}

The experiment was conducted during November 1999 to May 2000, in a protected area of the Center of Agricultural Sciences of the Federal University of Paraíba, in Brazil. The cultivars of guava tested were: Pentecoste (C1), Paluma (C2) Surubim (C3) and IPA B-38 (C4), the first has white pulp and others red pulp. Seeds of these cultivars were submitted to germination test under non saline condition according to Brasil, (1992), obtaining the percentages of $51 \%(\mathrm{C} 1)$ and (C2), $45 \%$ (C3) and 53\% (C4).

The substrate used for germination and initial growth was a mixture of equal parts of washed sand, earthworm humus and bovine manure of $\mathrm{C}: \mathrm{N}$ relation 12:1, conditioned in black polyethylene pots $(0.25 \mathrm{~m}$ high and $0.18 \mathrm{~m}$ in diameter) filled with $5.0 \mathrm{~L}$ of the substrate which presented salinity of 4.9 $\mathrm{dS} \mathrm{m}^{-1}$. For leaching of salts, before the sowing, the soil was washed with water of $\mathrm{EC}_{\mathrm{w}} 0.5 \mathrm{dS} \mathrm{m}^{-1}$ to reduce the substrate salinity to values below $2.0 \mathrm{dS} \mathrm{m}^{-1}$ (Lima et al., 2001).

For germination the treatments were distributed in a completely randomized design with 12 repetitions in factorial arrangement $5 \times 4$ referring to $\mathrm{EC}_{\mathrm{w}}: 0.5 ; 1.5 ; 3.0 ; 4.5$ and $6.0 \mathrm{dS} \mathrm{m}^{-1}$. Irrigation waters were obtained by dilution of a highly saline water from barrage $\left(27.0 \mathrm{dS} \mathrm{m}^{-1}\right)$, with distilled water (Cavalcante et al., 2001a).

Ten seeds were sown in each experimental unit and the emerged number of seedlings was registered daily until the stabilization of germination process after 41 days. For calculation, the number of germinated seeds in substratte irrigated with saline water was divided by ten and multiplied by the value obtained in laboratory test, referring to each cultivar. For statistical evaluation the data were transformed to $\operatorname{arcsen}[\mathrm{x}(\%) / 100]^{1 / 2}$.

At 60 days after germination it was observed that seedlings not supported the stress provoked by $\mathrm{EC}_{\mathrm{w}} 4.5$ and $6.0 \mathrm{dS} \mathrm{m}^{-1}$. Therefore the factorial $5 \times 4$ was reduced to $3 \times 4$, that is, involving only $\mathrm{EC}_{\mathrm{w}}$ levels of $0.5,1.5$ and $3.0 \mathrm{dS} \mathrm{m}^{-1}$ and the respective genotypes. The evaluation of growth, stem diameter and leaf area was performed at 60,120 and 180 days after sowing characterizing samples subdivided in time and factorial arrangement $3 \times 4 \times 3$. The dry mass of roots, stems and leaves were analysed, at the end of the experiment, in the factorial arrangement $3 \times 4$.

The irrigation was localized in order to avoid leaching or deposition of salts directly in stems and leaves, and consequently, reduce the effects of salinity in plants. After 60 days $200 \mathrm{~mL}$ of respective water based on losses by evaporation obtained by the weighing process were applied. After this period until the end of the experiment, the water application was done every $48 \mathrm{~h}$ and the volume applied intended to supply the evapotranspiration requirements.

The growth was measured with millimetred ruler, the stem diameter with a paquimeter (precision 1:50) and the leaf area was estimated by the product of the length and the maximum width, corrected by a coefficient determined through the relationship between the real area and the estimated area of each cultivar. The respective factors were: 0.758 (Pentecoste); 0.743 (Paluma); 0.745 (Surubim) and 0.758 (IPA B-38).

Statistical analyses to explain salinity effects included polynomial regression for germination data, and variance analysis through $\mathrm{F}$ test and mean confrontation by test of Tukey for growth, stem diameter, leaf area and dry matter of roots, stems and leaves (Ferreira, 2000).

\section{RESULTS AND DISCUSSION}

The increase of $\mathrm{EC}_{\mathrm{w}}$ of water inhibited germination of cultivars. The germination process of guava was more significantly affected in treatments irrigated with $\mathrm{EC}_{\mathrm{w}} 4.5$ and $6.0 \mathrm{dS} \mathrm{m}^{-1}$. Due to similarity of data (Figure 1), it is verified that 
there was no statistical difference among the cultivars, therefore the effect can be represented by a straight line or equation resulting from mean values of genotypes. This indicates that the depressive action of salts was congruent to germination in all cultivars as evidenced by Pereira (2000). This situation shows that plants of the same specie can behave similarily whether submitted to salinity of water or soil during germination phase as suggested by Bernstein (1964), Miguel et al. (1998) and Santos (1999).

At 60 days after sowing, seedings of cultivars did not support saline stress provoked in the substrate irrigated with $\mathrm{EC}_{\mathrm{w}} 4.5$ and $6.0 \mathrm{dS} \mathrm{m}^{-1}$. It shows that the cultivars studied were more sensitive to the salinity during initial growth phase and not in germination. This behavior although coherent with Pereira (2000) and Távora et al. (2001) diverges from that observed by Hooda \& Yamdagni (1991) which evidenced that guava was more sensitive to saline effects during germination than in initial growth phase. This inversion of behavior can be caused by genetic variability of the crop. In this direction Strogonov (1964) studied physiological bases of plants to salts and concluded that cultivars of the same specie and even the plants of the same cultivar can present a different behavior when submitted to salinity in relation to vegetative stage.

At 60 days after sowing the $\mathrm{EC}_{\mathrm{w}}$ increase from 0.5 up to 3.0 $\mathrm{dS} \mathrm{m}^{-1}$, reducing significantly the growth of the cultivars, except for Pentecoste (Table 1A), registering decreases of $29.11 \%(\mathrm{C} 1)$, $20.04 \%(\mathrm{C} 2), 39.81 \%(\mathrm{C} 3)$ and $74.37 \%(\mathrm{C} 4)$. After 60 days the growth was statistically reduced in plants irrigated with $\mathrm{EC}_{\mathrm{W}}$ $1.5 \mathrm{dS} \mathrm{m}^{-1}$.

The comparison of growth in cultivars submitted to same saline level (Table 1A) shows that IPA B-38 (C4) was the cultivar that less grew up at 60 days, when irrigated with $\mathrm{EC}_{\mathrm{w}} 3.0$ $\mathrm{dS} \mathrm{m} \mathrm{m}^{-1}$. The same tendency was registered at 120 days with Surubim (C3) and at 180 days with Paluma (C2). The results of plants growth until 180 days revealed that plants of different cultivars grew differently under equal conditions of saline stress as presented Bernstein (1964) and Santos (1999). Statistically the depressive effect sequence on plant growth at 180 days of $\mathrm{EC}_{\mathrm{w}} 1.5$ and $3.0 \mathrm{dS} \mathrm{m}^{-1}$, was: Paluma $(50.73 \mathrm{~cm})=$ IPA B-38 $(53.50 \mathrm{~cm})>$ Surubim $(55.17 \mathrm{~cm})>$ Pentecoste $(65.83$ $\mathrm{cm})$ and Paluma $(33.13 \mathrm{~cm})=\operatorname{IPA}$ B-38 $(36-97 \mathrm{~cm})>$ Pentecoste $(39-50 \mathrm{~cm})>$ Surubim $(41-17 \mathrm{~cm})$ respectively, expressing that IPA B-38 and Paluma were the most affected cultivars in relation to plant growth.

The plant development in relation to stem diameter was decreased with $\mathrm{EC}_{\mathrm{w}}$ increase, independent of plant age after sowing. It is seen in Table $1 \mathrm{~A}$, as also observed in growth, that the saline effects were statistically significant for the treatments with $\mathrm{EC}_{\mathrm{w}}$ equal to $1.5 \mathrm{dS} \mathrm{m}^{-1}$, however the severest reductions were evidenced in plants irrigated with $\mathrm{EC}_{\mathrm{w}}$ of $3.0 \mathrm{dS} \mathrm{m}^{-1}$.

Guava revealed to be more sensible to salts in seedling formation phase, although there is evidence that from 60 to 180 days had been registered increments in stem diameter of $244 \%$ to Pentecoste cultivar, $179 \%$ to Paluma, $162 \%$ to Surubim and $328 \%$ to IPA B-38. However, these increases have not resulted in good quality seedlings in relation to that irrigated with $\mathrm{EC}_{\mathrm{w}}$ superior to $1.5 \mathrm{dS} \mathrm{m}^{-1}$ (Pereira, 2000; Távora et al., 2001).

After 180 days of sowing, the sequence of salt aggressiveness to stem diameter was observed showing, significant differences among cultivars (Table 1B) irrigated with $\mathrm{EC}_{\mathrm{w}} 1.5$ and $3.0 \mathrm{dS} \mathrm{m}^{-1}$ : Paluma $(5.50 \mathrm{~mm})=\mathrm{IPA}$ B-38 $(5.63 \mathrm{~mm})$ $>$ Surubim $(6.07 \mathrm{~mm})>$ Pentecoste $(6.93 \mathrm{~mm})$ and Pentecoste $(4.93 \mathrm{~mm})=\operatorname{IPA} B-38(5.10 \mathrm{~mm})>\operatorname{Paluma}(5.57 \mathrm{~mm})=$ Surubim $(5.57 \mathrm{~mm})$, respectively.

The increase of water salinity level did not reduce leaf area after 60 days of sowing. This behavior, different in relation to growth and stem diameter was not reflected in tolerance to salts. From this age (Table $1 \mathrm{C}$ ) the results evidence that electrical conductivity of water superior to $1.5 \mathrm{dS} \mathrm{m}^{-1}$ provoked toxicity to the point to compromise the biological value of
$\mathrm{C}_{1}$

$\mathrm{C}_{3}$

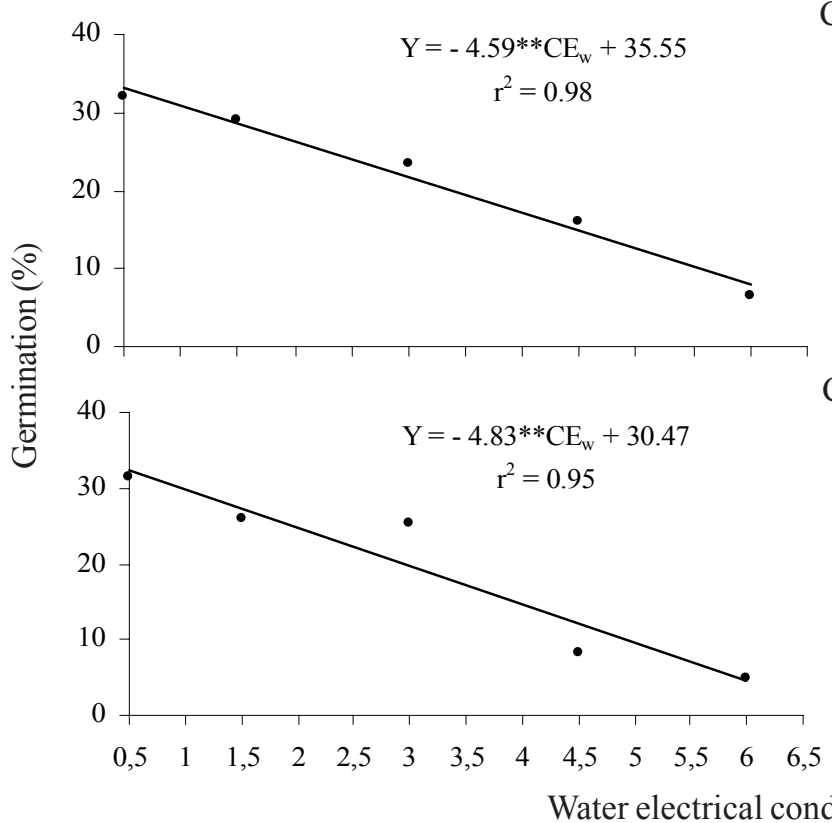

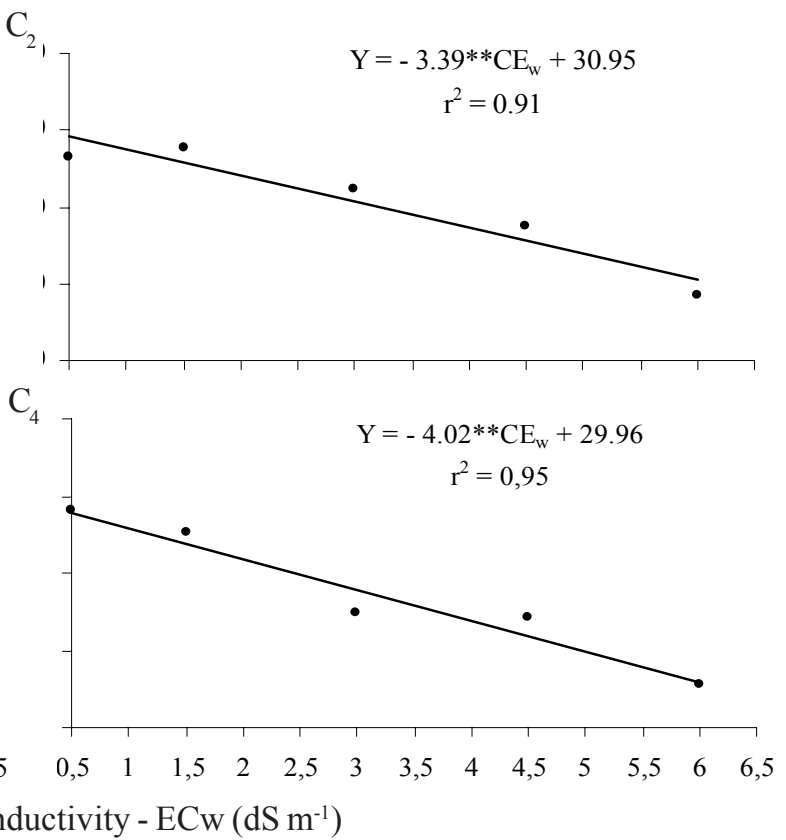

Figure 1. Seed germination of guava cultivars $\left(C_{1}=\right.$ Pentecoste; $C_{2}=$ Paluma; $C_{3}=$ Surubim e $\left.C_{4}=I P A B-38\right)$ as a function of water salinity $(* *$, significant at $\mathrm{P}<0,01$ ) 
Table 1. Growth of plants (A), steam diameter (B), leaf area (C), and dry matter production (D) of guava (Pisidium guajava L.) cultivars as a function of water salinity and plant age

\begin{tabular}{|c|c|c|c|c|c|c|c|c|c|}
\hline \multirow{2}{*}{ Cultivar } & \multicolumn{3}{|c|}{60 days } & \multicolumn{3}{|c|}{120 days } & \multicolumn{3}{|c|}{180 days } \\
\hline & 0.5 & 1.5 & 3.0 & 0.5 & 1.5 & 3.0 & 0.5 & 1.5 & 3.0 \\
\hline & \multicolumn{9}{|c|}{ A. Growth of plants $(\mathrm{cm})$} \\
\hline $\mathrm{C} 1$ & 7.9abA & $6.7 \mathrm{aA}$ & $5.6 \mathrm{abA}$ & $27.4 \mathrm{aA}$ & $23.6 \mathrm{aB}$ & $16.8 \mathrm{aC}$ & $67.4 \mathrm{aA}$ & $65.8 \mathrm{aA}$ & $39.5 \mathrm{abB}$ \\
\hline $\mathrm{C} 2$ & $6.6 \mathrm{bAB}$ & $8.8 \mathrm{aA}$ & $5.2 \mathrm{abB}$ & $26.0 \mathrm{aA}$ & $22.0 \mathrm{aB}$ & $12.5 \mathrm{bC}$ & $53.2 \mathrm{cA}$ & $50.7 \mathrm{cA}$ & $33.1 \mathrm{cB}$ \\
\hline $\mathrm{C} 3$ & $10.5 \mathrm{aA}$ & $7.7 \mathrm{aAB}$ & $6.3 \mathrm{aB}$ & $26.5 \mathrm{aA}$ & $23.5 \mathrm{aA}$ & $7.7 \mathrm{cB}$ & $50.0 \mathrm{cB}$ & $55.1 \mathrm{bA}$ & $41.1 \mathrm{aB}$ \\
\hline \multirow[t]{2}{*}{$\mathrm{C} 4$} & $8.3 \mathrm{abA}$ & $6.4 \mathrm{aA}$ & $2.1 \mathrm{bB}$ & $25.1 \mathrm{aA}$ & $13.9 \mathrm{bB}$ & $9.2 \mathrm{bcC}$ & $63.3 \mathrm{bA}$ & $53.5 \mathrm{bcB}$ & $36.9 \mathrm{bcC}$ \\
\hline & \multicolumn{9}{|c|}{ B. Stem diameter $(\mathrm{mm})$} \\
\hline $\mathrm{C} 1$ & $1.4 \mathrm{bC}$ & $2.2 \mathrm{aA}$ & $1.8 \mathrm{aB}$ & $3.7 \mathrm{aA}$ & $3.0 \mathrm{bB}$ & $2.6 \mathrm{aC}$ & $6.7 \mathrm{bA}$ & $6.9 \mathrm{aA}$ & $4.9 \mathrm{bB}$ \\
\hline $\mathrm{C} 2$ & $2.3 \mathrm{aA}$ & $2.3 \mathrm{aA}$ & $1.7 \mathrm{aB}$ & $3.7 \mathrm{abA}$ & $3.3 \mathrm{aB}$ & $2.4 \mathrm{aC}$ & $6.7 \mathrm{abA}$ & $5.5 \mathrm{cB}$ & $5.5 \mathrm{aB}$ \\
\hline $\mathrm{C} 3$ & $2.4 \mathrm{aA}$ & $2.1 \mathrm{abA}$ & $1.1 \mathrm{aB}$ & $3.3 \mathrm{bA}$ & $3.1 \mathrm{aA}$ & $1.8 \mathrm{bB}$ & $6.1 \mathrm{cA}$ & $6.1 \mathrm{bA}$ & $5.5 \mathrm{aB}$ \\
\hline \multirow[t]{2}{*}{$\mathrm{C} 4$} & $2.3 \mathrm{aA}$ & $1.8 \mathrm{bB}$ & $1.1 \mathrm{bC}$ & $3.4 \mathrm{bA}$ & $2.5 \mathrm{bB}$ & $2.5 \mathrm{aB}$ & $7.1 \mathrm{aA}$ & $5.6 \mathrm{cB}$ & $5.1 \mathrm{bC}$ \\
\hline & \multicolumn{9}{|c|}{ C. Leaf area $\left(\mathrm{cm}^{2}\right.$ plant $\left.^{-1}\right)$} \\
\hline $\mathrm{C} 1$ & $13.1 \mathrm{aA}$ & $46.3 \mathrm{aA}$ & $34.4 \mathrm{aA}$ & $523.5 \mathrm{aA}$ & $410.1 \mathrm{aB}$ & $269.8 \mathrm{aC}$ & $1218.6 \mathrm{bA}$ & $954.3 \mathrm{bcB}$ & $485.6 \mathrm{cC}$ \\
\hline $\mathrm{C} 2$ & $62.3 \mathrm{aA}$ & $51.1 \mathrm{aA}$ & $34.9 \mathrm{aA}$ & $538.6 \mathrm{aA}$ & $393.1 \mathrm{aB}$ & $198.5 \mathrm{aC}$ & $1258.7 \mathrm{abA}$ & $919.8 \mathrm{cB}$ & $660.2 \mathrm{bC}$ \\
\hline $\mathrm{C} 3$ & $128.1 \mathrm{aA}$ & $69.4 \mathrm{aA}$ & $47.1 \mathrm{aA}$ & $534.1 \mathrm{aA}$ & $366.8 \mathrm{aB}$ & $89.6 \mathrm{bC}$ & $1032.8 \mathrm{cA}$ & $1218.2 \mathrm{aB}$ & $682.3 \mathrm{bC}$ \\
\hline $\mathrm{C} 4$ & $93.7 \mathrm{aA}$ & $50.0 \mathrm{aA}$ & $10.0 \mathrm{aA}$ & $617.5 \mathrm{aA}$ & $248.8 b B$ & $118.8 \mathrm{aC}$ & $1360.6 \mathrm{aA}$ & $1008.5 \mathrm{bB}$ & $732.1 \mathrm{aC}$ \\
\hline
\end{tabular}

D. Dry matter $\left(\mathrm{g} \mathrm{plant}^{-1}\right)$

\begin{tabular}{|c|c|c|c|c|c|c|c|c|c|}
\hline & \multicolumn{3}{|c|}{ Roots } & \multicolumn{3}{|c|}{ Stems } & \multicolumn{3}{|c|}{ Leaves } \\
\hline $\mathrm{C} 1$ & 6.3abA & $3.7 \mathrm{aB}$ & $2.2 \mathrm{aB}$ & $4.7 \mathrm{aA}$ & 4.3aA & $2.7 \mathrm{aB}$ & $8.5 \mathrm{aA}$ & 8.4aA & $3.1 \mathrm{aB}$ \\
\hline $\mathrm{C} 2$ & $8.2 \mathrm{aA}$ & $3.9 \mathrm{aB}$ & $2.5 \mathrm{aB}$ & $4.3 \mathrm{aA}$ & $2.5 \mathrm{bB}$ & $1.9 \mathrm{aB}$ & 7.4abA & $5.8 \mathrm{abA}$ & $2.1 \mathrm{aB}$ \\
\hline $\mathrm{C} 3$ & $4.3 \mathrm{bA}$ & $3.0 \mathrm{aA}$ & $2.7 \mathrm{aA}$ & $4.0 \mathrm{aA}$ & $4.1 \mathrm{aA}$ & $2.2 \mathrm{aB}$ & $5.7 \mathrm{bAB}$ & 7.7aA & $3.9 \mathrm{aB}$ \\
\hline $\mathrm{C} 4$ & $4.8 \mathrm{bA}$ & $2.8 \mathrm{aA}$ & $3.5 \mathrm{aA}$ & $5.3 \mathrm{aA}$ & 3.4abB & $2.1 \mathrm{aC}$ & 7.9abA & $4.8 \mathrm{bB}$ & $4.4 \mathrm{aB}$ \\
\hline
\end{tabular}

(Pisidium guajava $\mathrm{L}$.) as a function of water salinity and plant age $0.5,1.5$ and $3.0 \mathrm{dSm}^{-1}=$ Water electrical conductivity; $\mathrm{C}_{1}=$ Pentecoste; $\mathrm{C}_{2}=$ Paluma; $\mathrm{C}_{3}=$ Surubim; $\mathrm{C}_{4}=\mathrm{IPA} \mathrm{B}-38 ;$ Averages not followed by same minuscule letter in columns $(\mathrm{smd}=3.62)$ and maiuscule in lines $(\mathrm{smd}=3.30)$ are different among them by Tukey's multiple range test at $5 \%$; smd $=$ Significant minimum difference

seedlings. This adversity is more common when the $\mathrm{EC}_{\mathrm{w}}$ was increased to levels that offer moderate $\left(0.75<\mathrm{EC}_{\mathrm{w}}<3.00 \mathrm{dSm}^{-1}\right)$ and severe restriction $\left(\mathrm{EC}_{\mathrm{w}}>3.00 \mathrm{dS} \mathrm{m}^{-1}\right)$ to the plants in initial growth phase (Ayers \& Westcot, 1999; Cavalcante et al., 2001b).

Except to Surubim (C3) and IPA B - 38 (C4) cultivars, the plant mass (Table 1D) was statistically reduced with the $\mathrm{EC}_{\mathrm{w}}$ increase after 180 days of sowing. The highest losses were registered in $\mathrm{EC}_{\mathrm{w}} 3.0 \mathrm{dS} \mathrm{m}^{-1}$, independent of organ or cultivar (Ayers \& Westcot, 1999).

Among the organs, the leaves were the most producer of dry matter, under any ionic concentration. These results are compatible with Santos (1999) and Lima et al. (2001) who produced seedlings of passion fruit and pine cone, irrigating with saline water from barrage and obtained biological incomes of leaves superior to roots and stems.

Except in roots of Surubim (C3) and IPA B-38 (C4), the increase of the water salinity decreased the dry matter production in organs of the plants (Table 1D). The reductions in stems and leaves were observed in plants irrigated with $\mathrm{EC}_{\mathrm{w}}$ $1.5 \mathrm{dS} \mathrm{m}^{-1}$ and above. This situation demonstrates that the plants of $\mathrm{C} 3$ and $\mathrm{C} 4$ acquired higher degree of tolerance, thus adjusted more adequately to the harmful effect of the salinity than $\mathrm{C} 1$ and $\mathrm{C} 2$ cultivars. If it is admitted that, after germination, the biological criterion that adquately expresses the osmorregulation of plants to salts is initiated by roots (Strogonov, 1964; Ayers \& Westcot, 1999; Cavalcante et al., 2001a) the superiority of $\mathrm{C} 3$ and $\mathrm{C} 4$ can be evidened in relation to $\mathrm{C} 1$ and $\mathrm{C} 2$ (Table 1D). It shows also that cultivars of the same specie can behave differently to salinity effects (Santos, 1999).

In relation to dry matter produced by stems and leaves, the decline was significantly higher in plants irrigated with $\mathrm{CE}_{w}$ equal or superior to $1.5 \mathrm{dS} \mathrm{m}^{-1}$, independent of cultivar. As proposed by Lauchi \& Epstein (1984), Kaul et al. (1988), Hooda \& Yamdagni (1991), Miguel et al. (1998) and Lima et al. (2001), dry matter production reflects the conditions of stress provoked in roots. Comparatively the highest accumulation of dry matter was produced by leaves, followed by roots and stems (Pereira, 2000).

\section{CONCLUSIONS}

1. The germination, plant growth, stem diameter, leaf area and dry matter production of roots, stems and leaves of guava were inhibited with the increase in electrical conductitity of irrigation water.

2. After germination the guava plants do not support the effect of electrical conductitity of irrigation water $\geq 4,5$ and 6,0 $\mathrm{dSm}^{-1}$.

3. The guava was more sensible to salinity in seedling formation than during germination phase.

4. The dry matter accumulation for different parts varied as: leaves $>$ roots $>$ stems. 
5. Seedlings irrigated with water salinity above $1.5 \mathrm{dS} \mathrm{m}^{-1}$ do not result in seedlings of good quality.

\section{LITERATURE CITED}

Ayers, R.S.; Westcot, D.W. A qualidade da água na agricultura. Campina Grande: UFPB, 1999. 153p.

Bernstein, L. Salt tolerance of plants. Washington: USDA, 1964. 23p. Information Bulletim, 283

Brasil. Ministério da Agricultura e Reforma Agrária. Regras para análise de sementes. Brasília: MARA. Teste de germinação. 1992. Cap. 5, p.79-138.

Cavalcante, L.F.; Carvalho, S.S. de.; Lima, E.M.; Feitosa Filho, J.C.; Silva, D.A. Desenvolvimento inicial da gravioleira sob fontes e níveis da salinidade da água. Revista Brasileira de Fruticultura, Jaboticabal, v.23, n.2, p.455-459, 2001 b.

Cavalcante, L.F.; Lima, E.M. de. Algumas frutíferas tropicais e a salinidade. Areia: Diniz, 2000.91p.

Cavalcante, L.F.; Lima, E.M. de.; Cavalcante, I.H.L. Possibilidade do uso de água salina no cultivo do maracujazeiro amarelo. Areia: Diniz, 2001b. 42p.

Ferreira, P.V. Estatística experimental aplicada à agronomia. 3.ed. Maceió: UFAL, 2000. 682p.

Gonzaga Neto, L.; Bezerra, J.E.F.; Abramof, L.; Pedrosa, A.C. Cultivo da goiabeira (Psidium guajava L.) nas condições do Vale do Rio Moxotó. Recife: Empresa Pernambucana de Pesquisa Agropecuária-IPA, 1982. 8p. Instruções Técnicas, 5

Gonzaga Neto, L.; Cristo, A.S.; Choudhury, M.M. Conservação pós-colheita de frutos de goiabeira, variedade Paluma. Pesquisa Agropecuária Brasileira, Brasília, v.34, n.1, p.1-6, 1999.

Hooda, P.S.; Yamdagni, R. Salt tolerance of guava (Psidium guajava L.) and Aonla (Emblica officinalis) at germination stage. Research and Development Reporter, Haryana, v.8, n.1,p.36-38, 1991.

Kaul, M.K. Studies on salt tolerance in guajava. Kurukshetra: Haryana Agricultural University, 1981. 125p. PhD Thesis

Kaul, M.K.; Mehta, P.K.; Baskshi, R.K. Note on effect of differents salts on seed germination of Psidium guajava L. Cv. L-49 (Sadar). Current Agriculture, Kurukshetra, v.12, n.12, p.83-85, 1988 .
Lauchi, A.; Epstein, E. Mechanisms of salt tolerance for plants. California Agriculture, Oakland,v.38, n.10, p.18-20, 1984.

Lima, K.L.; Cavalcante, L.F.; Feitosa Filho, J.C. Efeito de fontes e níveis de salinidade da água de irrigação sobre a germinação e o crescimento da pinheira. Engenharia Agrícola, Jaboticabal, v.21, n.2, p.135-144, 2001.

Makhija, M.; Dhankhar, O.P.; Singhrot, R.S. Effect of soil salinity levels on growth and leaf mineral composition of guava (Psidium guajava L.). Haryana Journal of Horticultural Science, Kurukshetra, v.9, n.1-2, p.21-25, 1980.

Mayer, A.M.; Poljakoff-Mayber, A. The germination of seeds. Oxford: Pergamom, 1989.270p.

Miguel, A.A.; Santos, J.B. dos.; Alves, G.S.; Sá, J.R.; Santos, C.J.O.; Queirós, M.S.; Cavalcante, L.F. Influência da salinidade da água de irrigação e do substrato sobre a germinação de sementes e crescimento inicial do maracujazeiro amarelo. Anais do CPG em Manejo de Solo e Água, Areia, v.20, p.32-39, 1998.

Pereira, K.S.N. Tolerância varietal da goiabeira à salinidade da água de irrigação durante a germinação e produção de mudas. Areia: UFPB, 2000. 82p. Dissertação Mestrado

Santos, J.B. dos. Produção e qualidade de mudas de maracujazeiro irrigado com água salina. Areia: UFPB, 1999. 57p. Monografia

Strogonov, B.D. Physiological basis of salt tolerance of plants. Jerusalém: Program for Scientific Translation, 1964. 279p.

Távora, F.J.A.F.; Ferreira, R.G.; Hernandez, F.F.F. Crescimento e relações hídricas em plantas de goiabeira submetidas a estresse salino com $\mathrm{NaCl}$. Revista Brasileira de Fruticultura, Jaboticabal, v.23, n.2, p.441-446, 2001.

Zuazo, V.H.D.; Martínez-Raya, A.; Ruiz, J.A. Salt tolerance of mango rootstocks (Magnifera indica L. cv. Osten). Spanish Journal of Agricultural Research, Madrid, v.1, n.1, p.67-78, 2003.

Zuazo, V.H.D.; Martínez-Raya, A.; Ruiz, J.A.; Tarifa, D.F. Impact of salinity on macro and micronutrient uptake in mango (Magnifera indica L. cv. Osten). Spanish Journal of Agricultural Research, Madrid, v.2, n.1, p.121-133, 2004. 